\title{
Organotin(IV) Complexes with 2-Acetylpyridine Benzoyl Hydrazones: Antimicrobial Activity
}

\author{
Angel A. R. Despaigne, ${ }^{a, \#}$ Lorena F. Vieira, ${ }^{a}$ Isolda C. Mendes, ${ }^{a}$ \\ Fernanda B. da Costa, ${ }^{a}$ Nivaldo L. Speziali ${ }^{b}$ and Heloisa Beraldo*,a \\ ${ }^{a}$ Departamento de Química and ${ }^{b}$ Departamento de Física, Universidade Federal de Minas Gerais, \\ 31270-901 Belo Horizonte-MG, Brazil
}

\begin{abstract}
Reações de tricloreto de $n$-butilestanho, $\left[\mathrm{Bu}^{\mathrm{n} S n C l}{ }_{3}\right]$, e tricloreto de fenilestanho, $\left[\mathrm{PhSnCl}_{3}\right]$, com 2-acetilpiridina benzoil hidrazona $(\mathrm{H} 2 \mathrm{AcPh})$, 2-acetilpiridina-para-cloro-benzoil hidrazona $(\mathrm{H} 2 \mathrm{Acp} \mathrm{ClPh})$ e 2-acetilpiridina-para-nitro benzoil hidrazona $\left(\mathrm{H}_{2} \mathrm{Ac} p \mathrm{NO}_{2} \mathrm{Ph}\right)$ produziram os complexos $\left[\mathrm{Bu}^{\mathrm{n}} \mathrm{Sn}(2 \mathrm{AcPh}) \mathrm{Cl}_{2}\right](\mathbf{1}),\left[\mathrm{Bu}^{\mathrm{n}} \mathrm{Sn}(2 \mathrm{Ac} p \mathrm{ClPh}) \mathrm{Cl}_{2}\right](\mathbf{2}),\left[\mathrm{Bu}^{\mathrm{n}} \mathrm{Sn}\left(2 \mathrm{Ac} p \mathrm{NO}_{2} \mathrm{Ph}\right) \mathrm{Cl}_{2}\right]$ (3), $\left[\mathrm{PhSn}(2 \mathrm{AcPh}) \mathrm{Cl}_{2}\right](\mathbf{4}),\left[\mathrm{PhSn}(2 \mathrm{Acp} \mathrm{ClPh}) \mathrm{Cl}_{2}\right](\mathbf{5})$ e $\left[\mathrm{PhSn}\left(2 \mathrm{Ac} p \mathrm{NO}_{2} \mathrm{Ph}\right) \mathrm{Cl}_{2}\right](\mathbf{6}) . \mathrm{H} 2 \mathrm{Acp} \mathrm{ClPh}$ revelou-se a hidrazona mais ativa contra Staphylococcus aureus e Candida albicans. Pela coordenação a atividade antibacteriana tanto do metal quanto das hidrazonas aumenta significativamente. Os complexos 2 e 5 revelaram-se os mais ativos como agentes antimicrobianos.
\end{abstract}

Reaction of $n$-butyltin trichloride, $\left[\mathrm{Bu}^{\mathrm{n}} \mathrm{SnCl}_{3}\right]$, and phenyltin trichloride, $\left[\mathrm{PhSnCl}_{3}\right]$, with 2-acetylpyridine benzoyl hydrazone ( $\mathrm{H} 2 \mathrm{AcPh}), 2$-acetylpyridine para-chloro-benzoyl hydrazone $(\mathrm{H} 2 \mathrm{Ac} p \mathrm{ClPh})$ and 2-acetylpyridine para-nitro-benzoyl hydrazone $\left(\mathrm{H} 2 \mathrm{Ac} p \mathrm{NO}_{2} \mathrm{Ph}\right)$ gave $\left[\mathrm{Bu}^{\mathrm{n}} \mathrm{Sn}(2 \mathrm{AcPh}) \mathrm{Cl}_{2}\right](\mathbf{1}),\left[\mathrm{Bu}^{\mathrm{n}} \mathrm{Sn}(2 \mathrm{Ac} p \mathrm{ClPh}) \mathrm{Cl}_{2}\right]$ (2), [ $\left.\mathrm{Bu}^{\mathrm{n}} \mathrm{Sn}\left(2 \mathrm{Ac} p \mathrm{NO}_{2} \mathrm{Ph}\right) \mathrm{Cl}_{2}\right](3),[\mathrm{PhSn}(2 \mathrm{AcPh})$ $\left.\mathrm{Cl}_{2}\right](4),\left[\mathrm{PhSn}(2 \mathrm{Ac} p \mathrm{ClPh}) \mathrm{Cl}_{2}\right](\mathbf{5})$ and $\left[\mathrm{PhSn}\left(2 \mathrm{Ac} p \mathrm{NO}_{2} \mathrm{Ph}\right) \mathrm{Cl}_{2}\right](\mathbf{6})$ as products. Among the hydrazones $\mathrm{H} 2 \mathrm{Acp} \mathrm{ClPh}$ proved to be the most active against Staphylococcus aureus and Candida albicans. Upon coordination the antibacterial activity of both tin and the hydrazones significantly increases. Complexes $\mathbf{2}$ and $\mathbf{5}$ revealed to be the most active as antimicrobial agents.

Keywords: 2-acetylpyridine benzoyl hydrazones, organotin(IV) complexes, crystal structures, antimicrobial activity

\section{Introduction}

Hydrazones are a versatile class of compounds which present a wide range of biological applications as antimicrobial, ${ }^{1}$ antitubecular, ${ }^{2}$ anticonvulsant, ${ }^{3}$ antiinflammatory, ${ }^{4}$ cytotoxic ${ }^{5}$ and vasodilator ${ }^{6}$ agents. Moreover, 9-acridanone-hydrazones proved to be active against Schistosoma mansoni ${ }^{7}$ and quinoxaline- $N$ acylhydrazones showed trypanocidal activity. ${ }^{8}$ In addition, methyl pyrazinylketone isonicotinoyl hydrazones have been synthesized in an attempt to develop novel chelators with high affinity for iron for the treatment of iron overload disease. ${ }^{9}$

Hydrazones also proved to be useful as sensitive analytical reagents for the determination of trace amounts of metal ions..$^{10,11}$ Metal complexes with hydrazones have

*e-mail: hberaldo@ufmg.br

"On leave from Universidad de Oriente, Santiago de Cuba, Cuba potential applications as catalysts, ${ }^{12}$ luminescent probes, ${ }^{13}$ and molecular sensors. ${ }^{14}$ Moreover, metal complexes with hydrazones present antimicrobial, ${ }^{15-17}$ DNA-binding and cytotoxic activities. ${ }^{17}$ It has also been shown that metal complexes with hydrazones can be potent inhibitors of cell growth and DNA syntheses. ${ }^{18}$

Tin compounds present applications as PVC stabilizers, ${ }^{19}$ for chemical vapor decomposition (CVD), ${ }^{20}$ in non-linear optics $^{21}$ and in catalyses. ${ }^{22}$ Organotin complexes present innumerous pharmacological applications as antitumorals, ${ }^{23}$ antimicrobials ${ }^{24,25}$ and biocides. ${ }^{26}$ The cytotoxic activity of a variety of organotin complexes against tumor cell lines has been demonstrated by some of us. ${ }^{27,28}$

In recent works we started an investigation on metal complexes of pyridine-derived hydrazones..$^{29-31}$ In the present paper organotin(IV) complexes were prepared by reacting $\left[\mathrm{Bu}^{\mathrm{n}} \mathrm{SnCl}_{3}\right]$ and $\left[\mathrm{PhSnCl}_{3}\right]$ with 2-acetylpyridine-benzoyl hydrazone $(\mathrm{H} 2 \mathrm{AcPh}), 2$-acetylpyridine para-chlorobenzoyl hydrazone $(\mathrm{H} 2 \mathrm{Acp} \mathrm{ClPh})$ and 2-acetylpyridine 
para-nitro-benzoyl hydrazone $\left(\mathrm{H} 2 \mathrm{Ac} \mathrm{NO}_{2} \mathrm{Ph}\right)$ (see Figure 1). The antimicrobial activity of the hydrazones and their organotin(IV) complexes was evaluated against Candida albicans and Staphylococcus aureus.

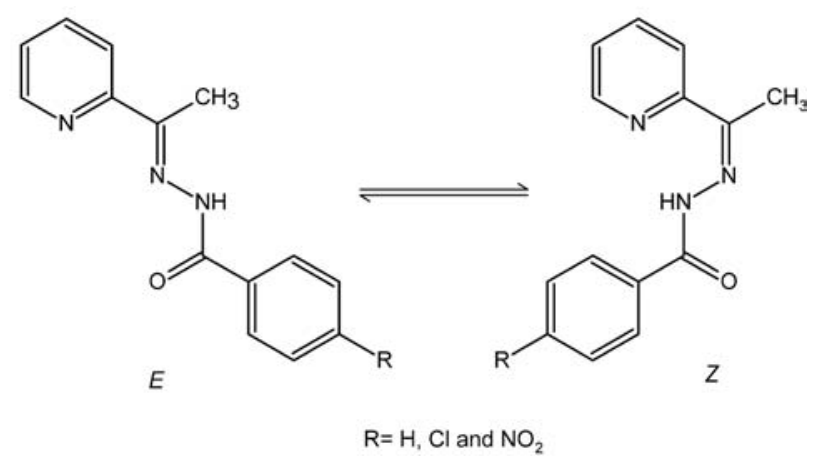

Figure 1. Generic structure of 2-acetylpyridine benzoyl hydrazones $(E$ and $Z$ configurational isomers).

\section{Experimental}

Apparatus

Partial elemental analyses were performed on a Perkin Elmer CHN 2400 analyzer. Infrared spectra were recorded on a Perkin Elmer FT-IR Spectrum GX spectrometer using CsI pellets; an YSI model 31 conductivity bridge was employed for molar conductivity measurements; NMR spectra were obtained with a Bruker DPX-200 (200 MHz) spectrometer or with a Bruker DRX-400 Avance (400 $\mathrm{MHz})$ spectrometer using deuterated dimethylsulfoxide (dmso- $d_{6}$ ) or deuterated chloroform $\left(\mathrm{CDCl}_{3}\right)$. The ${ }^{1} \mathrm{H}$ and ${ }^{13} \mathrm{C}$ NMR chemical shifts in ppm are reported from internal tetramethylsilane (tms) on the $\%$ scale. The ${ }^{119} \mathrm{Sn}$ NMR spectra were measured relative to $\mathrm{Sn}\left(\mathrm{CH}_{3}\right)_{4}$. Bruker standard experiments were performed using decoupling sequences for ${ }^{13} \mathrm{C}$ and ${ }^{119} \mathrm{Sn}$. Splitting patterns are designated as follows: $\mathrm{s}$ singlet; $\mathrm{d}$ doublet; $\mathrm{t}$ triplet; $\mathrm{q}$ quartet; m multiplet.

n-Butyltin trichloride, phenyltin trichloride, 2-acetylpyridine, benzoyl hidrazide, 4-chloro benzoyl hidrazide, and 4-nitro benzoyl hidrazide were purchased from Sigma-Aldrich and used without further purification. All other chemicals and solvents were of analytical grade.

Syntheses of 2-acetylpyridine-benzoyllhydrazone (H2AcPh), 2-acetylpyridine-para-chloro-benzoyl hydrazone (H2AcpClPh) and 2-acetylpyridine-para-nitro-benzoyl hydrazone $\left(\mathrm{H}_{2} \mathrm{AcpNO}_{2} \mathrm{Ph}\right)$

2-Acetylpyridine-benzoyl hydrazone ( $\mathrm{H} 2 \mathrm{AcPh})$ and 2-acetylpyridine-para-chloro-benzoyl hydrazone
$(\mathrm{H} 2 \mathrm{Ac} p \mathrm{ClPh})$ were prepared as described in the literature. ${ }^{32,33}$ 2-Acetylpyridine-para-nitro-benzoyl hydrazone $\left(\mathrm{H} 2 \mathrm{Ac} p \mathrm{NO}_{2} \mathrm{Ph}\right)$ was obtained by mixing equimolar amounts of 2-acetylpyridine with the para-nitrobenzoyl hydrazide in methanol with addition of three drops of acetic acid as catalyst. The reaction mixture was kept under reflux for $6 \mathrm{~h}$. After cooling to room temperature the resulting solid was filtered off, washed with ethanol and ether and dried in vaccuum.

H2AcpNO${ }_{2}$ Ph: Color: Beige; Yield: $88 \%$; mp 220-224 ${ }^{\circ} \mathrm{C}$. Selected IR bands $\left(v_{\max } / \mathrm{cm}^{-1}\right): v(\mathrm{NH}) 3188 \mathrm{~m}$; $v(\mathrm{C}=\mathrm{O}) 1676 \mathrm{~s} ; \mathrm{v}(\mathrm{C}=\mathrm{C})+v(\mathrm{CN}) 1580 \mathrm{~m} ; 1458 \mathrm{~m} ; 1429 \mathrm{~m}$; $\rho$ (py) $615 \mathrm{~m} .{ }^{1} \mathrm{H}$ NMR (dmso- $d_{6}, 400 \mathrm{MHz}, \delta$ ppm): 11.21 (s, 1H, NH); 8.64 (d, 1H, H6); 8.38 [d, 2H, H(11,13)]; 8.19 [d, 2H, H(10,14)]; 8.16(d,1H, H3); 7.91 (t, 2H, H4); 7.47(t, $1 \mathrm{H}, \mathrm{H} 5) ; 2.50$ (s, $3 \mathrm{H}, \mathrm{CH}_{3}$ ). ${ }^{13} \mathrm{C}$ NMR (dmso- $d_{6}, 400 \mathrm{MHz}$, ppm): $\delta$ 162.69(C6); 154.76 (C7); 149.10 (C2); 148.57(C6); 139.61(C12); 136.61 (C4); 134.06(C9); 129.52(C10,14); 124.25 (C5); 123.30(C11,13); 120.43 (C3).

Synthesis of $\left[\mathrm{Bu}^{n} \mathrm{Sn}(2 \mathrm{AcPh}) \mathrm{Cl}_{2}\right](\mathbf{1}),\left[\mathrm{Bu}^{n} \mathrm{Sn}(2 \mathrm{AcpClPh}) \mathrm{Cl}_{2}\right]$ (2), $\left[\mathrm{Bu}^{n} \mathrm{Sn}\left(2 \mathrm{AcpNO}_{2} \mathrm{Ph}\right) \mathrm{Cl}_{2}\right]$ (3), [PhSn $\left.(2 \mathrm{AcPh}) \mathrm{Cl}_{2}\right]$ (4), $\left[\mathrm{PhSn}(2 \mathrm{AcpClPh}) \mathrm{Cl}_{2}\right](5)$ and $\left[\mathrm{PhSn}\left(2 \mathrm{AcpNO}_{2} \mathrm{Ph} \mathrm{Cl}_{2}\right]\right.$ (6)

The organotin(IV) complexes were obtained by refluxing an ethanol solution of the desired hydrazone with $\left[\mathrm{Bu}^{\mathrm{n}} \mathrm{SnCl}_{3}\right]$ or $\left[\mathrm{PhSnCl}_{3}\right]$ in 1:1 ligand-to-metal molar ratio. The solids were washed with ethanol followed by diethylether and then dried in vaccuum. Crystals of complexes 1, 2, 3 and $\mathbf{5}$ were obtained from their ethanolic solutions and were stable in the air. Slow evaporation of 6 in 1:9 dmso:acetone solution gave crystals of $\left[\mathrm{PhSn}\left(2 \mathrm{AcpNO}_{2} \mathrm{Ph}\right) \mathrm{Cl}_{2}\right] \cdot d \mathrm{dmso},(6 \mathbf{6})$.

n-Butyl(dichloro)(2-acetylpyridinephenylhydrazonato)tin(IV), [Bun $\mathrm{Sn}\left(2 \mathrm{AcPh}^{\mathrm{C}} \mathrm{Cl}_{2}\right],(\mathbf{1})$ : Color: Yellow. Yield: $71 \%$. Anal. Calc. $\left(\mathrm{C}_{18} \mathrm{H}_{21} \mathrm{Cl}_{2} \mathrm{~N}_{3} \mathrm{OSn}\right)$ : C, 44.88; H, 4.36; N, 8.66. Found: C, 44.87; H, 4.16; $\mathrm{N}, 8.96 \%$. Selected IR bands $\left(v_{\max } / \mathrm{cm}^{-1}\right): v_{a s}\left(\mathrm{CH}_{3}\right) 2952$ $\mathrm{m} ; v_{s}\left(\mathrm{CH}_{3}\right) 2869 \mathrm{~m} ; v_{a s}\left(\mathrm{CH}_{2}\right) 2925 \mathrm{~m} ; v_{s}\left(\mathrm{CH}_{2}\right) 2853$ $\mathrm{m}$; v(C-H)ar $3060 \mathrm{~m} ; \mathrm{v}(\mathrm{C}=\mathrm{N}) 1599 \mathrm{~m} ; \sigma_{a s}\left(\mathrm{CH}_{2}\right)$ 1460; $\sigma_{a s}\left(\mathrm{CH}_{3}\right) 1421 ; \sigma_{s}\left(\mathrm{CH}_{3}\right) 1380 ; \rho(\mathrm{py}) 649 \mathrm{~m} ; \nu\left(\mathrm{M}-\mathrm{N}_{\text {imine }}\right)$ 492; v(M-O) 392; v(M-C) 349; v(M-Cl) 250; v(M-N py $_{\text {py }}$ ) 228. ${ }^{1} \mathrm{H}$ NMR $\left(\mathrm{CDCl}_{3}, 200 \mathrm{MHz}, \mathrm{ppm}\right): \delta 8.62(\mathrm{~d}, 1 \mathrm{H}$, H6); 8.34 (d, 2H, H10,14); 8.20 (t, 1H, H4); 8.01(d, 1H, H3); 7.74 (t, 1H, H5); 7.49(m, 3H, H11,13, H12); 2.82 (s, $3 \mathrm{H}, \mathrm{H} 15) ; 2.33(\mathrm{t}, 2 \mathrm{H}, \mathrm{H} 16) ; 2.07(\mathrm{~m}, 2 \mathrm{H}, \mathrm{H} 17) ; 1.61(\mathrm{~m}$, $2 \mathrm{H}, \mathrm{H} 18) ; 1.05(\mathrm{t}, 3 \mathrm{H}, \mathrm{H} 19) .{ }^{13} \mathrm{C} \mathrm{NMR}\left(\mathrm{CDCl}_{3}, 200 \mathrm{MHz}\right.$, ppm): $\delta$ 171.38(C8); 145.13(C6); 144.68(C7); 144.16(C2); 142.49(C4); 132.51(C12); 132.42(C9); 129.00(C10,14); 
128.15(C11,13); 127.05(C5); 125.06(C3); 35.50(C16); 27.51(C17); 25.60(C18); 13.68(C19); 13.53(C15). ${ }^{119} \mathrm{Sn}$ NMR $\left(\mathrm{CDCl}_{3}, 200 \mathrm{MHz}, \mathrm{ppm}\right): \delta-414.39$. Molar conductivity $\left(1 \times 10^{-3} \mathrm{~mol} \mathrm{~L}^{-1}, \mathrm{dmf}\right): 11.56 \Omega^{-1} \mathrm{~cm}^{2} \mathrm{~mol}^{-1}$.

n-Butyl(dichloro)(2-acetylpyridine-para-chlorophenylhydrazonato)tin(IV), [Bu $\left.\mathrm{Sn}(2 \mathrm{AcpClPh}) \mathrm{Cl}_{2}\right],(2)$ : Color: Yellow. Yield: $83 \%$. Anal. Calc. $\left(\mathrm{C}_{18} \mathrm{H}_{21} \mathrm{Cl}_{3} \mathrm{~N}_{3} \mathrm{OSn}\right)$ : C, 41.62; H, 3.88; N, 8.09. Found: C, 41.77; H, 3.41; N, $8.39 \%$. Selected IR bands $\left(v_{\max } / \mathrm{cm}^{-1}\right): v_{a s}\left(\mathrm{CH}_{3}\right) 2957 \mathrm{~m}$; $v_{s}\left(\mathrm{CH}_{3}\right) 2870 \mathrm{~m} ; v_{a s}\left(\mathrm{CH}_{2}\right) 2928 \mathrm{~m} ; v_{s}\left(\mathrm{CH}_{2}\right) 2859 \mathrm{~m} ; \mathrm{v}(\mathrm{C}-\mathrm{H})$ ar $3081 \mathrm{~m} ; v(\mathrm{C}=\mathrm{N}) 1599 \mathrm{~m} ; \sigma_{a s}\left(\mathrm{CH}_{2}\right) 1448 ; \sigma_{a s}\left(\mathrm{CH}_{3}\right) 1448$; $\sigma_{s}\left(\mathrm{CH}_{3}\right) 1386 ; \rho\left(\right.$ py) $647 \mathrm{~m} ; \mathrm{v}\left(\mathrm{M}-\mathrm{N}_{\text {imine }}\right) 481 ; \mathrm{v}(\mathrm{M}-\mathrm{O}) 402$; $v(\mathrm{M}-\mathrm{C}) 360 ; \mathrm{v}(\mathrm{M}-\mathrm{Cl}) 250 ; \mathrm{v}\left(\mathrm{M}_{\mathrm{p}} \mathrm{N}_{\mathrm{py}}\right) 228 .{ }^{1} \mathrm{H} \mathrm{NMR}\left(\mathrm{CDCl}_{3}\right.$, $200 \mathrm{MHz}, \mathrm{ppm}): \delta 8.63(\mathrm{~d}, 1 \mathrm{H}, \mathrm{H6}) ; 8.24(\mathrm{~d}, 2 \mathrm{H}, \mathrm{H} 10,14)$; 8.20(m, 1H, H4); 8.02(d, 1H, H3); 7.67(t, 1H, H5); 7.44(d, 2H, H11,13); 2.81(s, 3H, H15); 2.32(t, 2H, H16); 2.08(m, $2 \mathrm{H}, \mathrm{H} 17) ; 1.60(\mathrm{~m}, 2 \mathrm{H}, \mathrm{H} 18) ; 1.05(\mathrm{~s}, 3 \mathrm{H}, \mathrm{H} 19) .{ }^{13} \mathrm{C} \mathrm{NMR}$ $\left(\mathrm{CDCl}_{3}, 200 \mathrm{MHz}, \mathrm{ppm}\right): \delta 170.50$ (C8); 145.28(C6); 145.05(C7); 144.14(C2); 142.56(C4); 138.66(C12); 130.98(C9); 130.43(C11,13); 128.13(C10,14); 127.26(C5); 125.20(C3); 35.60(C16); 27.52(C17); 25.61(C18); 13.68(C19); 13.56(C15). ${ }^{119} \mathrm{Sn} \mathrm{NMR}\left(\mathrm{CDCl}_{3}, 200 \mathrm{MHz}\right.$, $\mathrm{ppm}): \delta-413.66$. Molar conductivity $\left(1 \times 10^{-3} \mathrm{~mol} \mathrm{~L}^{-1}, \mathrm{dmf}\right)$ : $14.33 \Omega^{-1} \mathrm{~cm}^{2} \mathrm{~mol}^{-1}$.

n-Butyl(dichloro)(2-acetylpyridine-para-nitrophenylhydrazonato)tin(IV), [ $\left.\mathrm{Bu}^{n} \mathrm{Sn}\left(2 \mathrm{AcpNO}_{2} \mathrm{Ph}\right) \mathrm{Cl}_{2}\right],(3)$ : Color: Yellow. Yield: $74 \%$. Anal. Calc. $\left(\mathrm{C}_{18} \mathrm{H}_{20} \mathrm{Cl}_{2} \mathrm{~N}_{4} \mathrm{O}_{3} \mathrm{Sn}\right)$ : C, 40.79; H, 3.80; N, 10.57. Found: C, 40.92; H, 3.72; N, $10.48 \%$. Selected IR bands $\left(v_{\max } / \mathrm{cm}^{-1}\right): v_{a s}\left(\mathrm{CH}_{3}\right) 2956 \mathrm{~m}$; $v_{s}\left(\mathrm{CH}_{3}\right) 2869 \mathrm{~m} ; \mathrm{v}_{a s}\left(\mathrm{CH}_{2}\right) 2927 \mathrm{~m} ; \mathrm{v}_{s}\left(\mathrm{CH}_{2}\right) 2858 \mathrm{~m} ; \mathrm{v}(\mathrm{C}-\mathrm{H})$ ar $3077 \mathrm{~m} ; v(\mathrm{C}=\mathrm{N}) 1596 \mathrm{~m} ; \sigma_{a s}\left(\mathrm{CH}_{2}\right) 1456 ; \sigma_{a s}\left(\mathrm{CH}_{3}\right) 1443$; $\sigma_{s}\left(\mathrm{CH}_{3}\right) 1384 ; \rho\left(\right.$ py) $649 \mathrm{~m} ; \mathrm{v}\left(\mathrm{M}-\mathrm{N}_{\text {imine }}\right) 479 ; \mathrm{v}(\mathrm{M}-\mathrm{O})$ 394; v(M-C) 364; v(M-Cl) 249; v( $\left({\mathrm{M}-\mathrm{N}_{\mathrm{py}}}\right) 214 .{ }^{1} \mathrm{H} \mathrm{NMR}$ $\left(\mathrm{CDCl}_{3}, 200 \mathrm{MHz}, \mathrm{ppm}\right): \delta 8.68(\mathrm{~d}, 1 \mathrm{H}, \mathrm{H} 6) ; 8.49(\mathrm{~d}, 2 \mathrm{H}$, $\mathrm{H} 10,14) ; 8.30(\mathrm{~m}, 2 \mathrm{H}, \mathrm{H} 11,13) ; 8.28(\mathrm{~m}, 1 \mathrm{H}, \mathrm{H} 4) ; 8.11(\mathrm{~d}$, 1H, H3); 7.84(t, 1H, H5); 2.87(s, 3H, H15); 2.34(t, 2H, $\mathrm{H} 16) ; 2.05(\mathrm{~m}, 2 \mathrm{H}, \mathrm{H} 17) ; 1.61(\mathrm{~m}, 2 \mathrm{H}, \mathrm{H} 18) ; 1.05(\mathrm{t}, 3 \mathrm{H}$, H19). ${ }^{13} \mathrm{C}$ NMR ( $\left.\mathrm{CDCl}_{3} 200 \mathrm{MHz}, \mathrm{ppm}\right): 169.36(\mathrm{C} 8)$; 150.00(C7); 146.89(C2); 145.51(C6); 143.93(C12); 142.62(C4); 138.41(C9); 129.85(C10,14); 127.60(C5); 125.45(C3); 123.21(C11,13); 35.79(C16); 27.52(C17); 25.61(C18); 13.73(C19); 13.68(C15). ${ }^{119} \mathrm{Sn}$ NMR $\left(\mathrm{CDCl}_{3}, 200 \mathrm{MHz}, \mathrm{ppm}\right): \delta-412.33$. Molar conductivity $\left(1 \times 10^{-3} \mathrm{~mol} \mathrm{~L}^{-1}, \mathrm{dmf}\right): 10.66 \Omega^{-1} \mathrm{~cm}^{2} \mathrm{~mol}^{-1}$.

Phenyl(dichloro)(2-acetylpyridine-phenylhydrazonato) $\operatorname{tin}(\mathrm{IV}),\left[\mathrm{PhSn}(2 \mathrm{AcPh}) \mathrm{Cl}_{2}\right],(4)$ : Color: Yellow. Yield: 85\%. Anal. Calc. $\left(\mathrm{C}_{20} \mathrm{H}_{17} \mathrm{Cl}_{2} \mathrm{~N}_{3} \mathrm{OSn}\right): \mathrm{C}, 47.57$; H, 3.39; $\mathrm{N}, 8.32$. Found: C, 46.66; H, 3.06; N, 8.80\%. Selected
IR bands $\left(v_{\max } / \mathrm{cm}^{-1}\right): v(\mathrm{C}-\mathrm{H}) \operatorname{ar} 3061 \mathrm{~m} ; \mathrm{v}(\mathrm{C}=\mathrm{N}) 1600 \mathrm{~m}$; $\rho$ (py) $650 \mathrm{~m} ; \mathrm{v}\left(\mathrm{M}_{\mathrm{N}} \mathrm{N}_{\text {imine }}\right) 494 ; \mathrm{v}$ (M-C) 441; v(M-O) 395; $v(\mathrm{M}-\mathrm{Cl}) 242 ; \mathrm{v}\left(\mathrm{M}-\mathrm{N}_{\mathrm{py}}\right) 229 .{ }^{1} \mathrm{H} \mathrm{NMR}\left(\mathrm{CDCl}_{3}, 200 \mathrm{MHz}\right.$, ppm) main signals: $\delta 8.41(\mathrm{~m}, 1 \mathrm{H}, \mathrm{H} 4) ; 8.40(\mathrm{~m}, 1 \mathrm{H}, \mathrm{H} 6)$; 8.33(d, 2H, H17,21); 8.21(d, 2H, H10,14); 8.04(d, 1H, H3); 7.60(m, 1H, H5); 7.59(m, 3H, H18,19,20); 7.50(m, 1H, H12); 7.44(m, 2H, H11,13); 2.88(s, 3H, H15). ${ }^{13} \mathrm{C}$ NMR $\left(\mathrm{CDCl}_{3}, 200 \mathrm{MHz}, \mathrm{ppm}\right)$ main signals: $\delta 171.53(\mathrm{C} 8)$; 145.06(C6); 144.11(C2); 142.61(C4); 139.92(C16); 136.62(C17,21); 132.59(C12); 132.16(C9); 131.13(C19); 129.08(C10,14,18,19); 128.17(C11,13); 126.99(C5); 124.04(C3); 13.45(C15). ${ }^{119} \mathrm{Sn}$ NMR ( $\mathrm{CDCl}_{3}, 200 \mathrm{MHz}$, $\mathrm{ppm}): \delta-443.37$. Molar conductivity $\left(1 \times 10^{-3} \mathrm{~mol} \mathrm{~L}^{-1}, \mathrm{dmf}\right)$ : $20.51 \Omega^{-1} \mathrm{~cm}^{2} \mathrm{~mol}^{-1}$.

Phenyl(dichloro)(2-acetylpyridine-para-chlorophenylhydrazonato)tin(IV), [PhSn(2AcpClPh) $\left.\mathrm{Cl}_{2}\right]$ (5): Color: Yellow. Yield: $86 \%$. Anal. Calc. $\left(\mathrm{C}_{20} \mathrm{H}_{16} \mathrm{Cl}_{3} \mathrm{~N}_{3} \mathrm{OSn}\right)$ : C, 44.53; H, 2.99; N, 7.99. Found: C, 43.57; H, 2.82; N, $8.04 \%$. Selected IR bands $\left(v_{\max } / \mathrm{cm}^{-1}\right): v(\mathrm{C}-\mathrm{H})$ ar $3050 \mathrm{~m}$; $v(\mathrm{C}=\mathrm{N}) 1597 \mathrm{~m} ; \rho\left(\right.$ py) $647 \mathrm{~m} ; \mathrm{v}\left(\mathrm{M}_{\mathrm{N}} \mathrm{N}_{\text {imine }}\right) 476$; $v(\mathrm{M}-\mathrm{C})$ 443; v(M-O) 403; v(M-Cl) 260; v( M-N $\left._{\mathrm{py}}\right) 233 .{ }^{1} \mathrm{H}$ NMR $\left(\mathrm{CDCl}_{3}, 200 \mathrm{MHz}, \mathrm{ppm}\right): \delta 8.42(\mathrm{~m}, 1 \mathrm{H}, \mathrm{H} 6) ; 8.40(\mathrm{~m}, 1 \mathrm{H}$, H4); 8.27(d, 2H, H17,21); 8.21(d, 2H, H11,13); 8.06(d, 1H, H3); 7.63(t, 1H, H5); 7.59(m, 3H, H18, 19,20); 7.41(d, 2H, $\mathrm{H} 10,14) ; 2.88(\mathrm{~s}, 3 \mathrm{H}, \mathrm{C} 15) .{ }^{13} \mathrm{C} \mathrm{NMR}\left(\mathrm{CDCl}_{3}, 200 \mathrm{MHz}\right.$, ppm): $\delta 170.58(\mathrm{C} 8) ; 145.11(\mathrm{C} 6) ; 144.46(\mathrm{C} 7) ; 144.07(\mathrm{C} 2)$; 142.77(C4); 139.75(C16); 138.76(C12); 136.50(C17,21); 131.22(C19); 131.00(C9); 130.47(18,20); 129.13(C11,13); 128.50(C10,14); 127.12(C5); 125.04(C3); 13.47(C15). ${ }^{119} \mathrm{Sn}$ NMR $\left(\mathrm{CDCl}_{3}, 200 \mathrm{MHz}, \mathrm{ppm}\right): \delta-442.65$. Molar conductivity $\left(1 \times 10^{-3} \mathrm{~mol} \mathrm{~L}^{-1}, \mathrm{dmf}\right): 20.53 \Omega^{-1} \mathrm{~cm}^{2} \mathrm{~mol}^{-1}$.

Phenyl(dichloro)(2-acetylpyridine-para-nitrophenylhydrazonato $) \operatorname{tin}(\mathrm{IV}),\left[\mathrm{PhSn}\left(2 \mathrm{AcpNO}_{2} \mathrm{Ph}\right) \mathrm{Cl}_{2}\right],(\boldsymbol{6})$ : Color: Yellow. Yield: 82\%. Anal. Calc. $\left(\mathrm{C}_{20} \mathrm{H}_{16} \mathrm{Cl}_{2} \mathrm{~N}_{4} \mathrm{O}_{3} \mathrm{Sn}\right)$ : C, 43.68; H, 2.93; N, 10.19. Found: C, 43.23; H, 3.00; $\mathrm{N}, 10.28 \%$. Selected IR bands $\left(v_{\max } / \mathrm{cm}^{-1}\right): v(\mathrm{C}-\mathrm{H}) \mathrm{ar}$ $3058 \mathrm{~m} ; \mathrm{v}(\mathrm{C}=\mathrm{N}) 1596 \mathrm{~m} ; \rho\left(\right.$ py) $649 \mathrm{~m} ; \mathrm{v}\left(\mathrm{M}-\mathrm{N}_{\text {imine }}\right)$ 486; v(M-C) 450; v(M-O) 394; v(M-Cl) 250; v( $\left(\mathrm{M}-\mathrm{N}_{\mathrm{py}}\right)$ 231. ${ }^{1} \mathrm{H}$ NMR $\left(\mathrm{CDCl}_{3}, 200 \mathrm{MHz}, \mathrm{ppm}\right): \delta 8.50(\mathrm{~d}, 2 \mathrm{H}$, $\mathrm{H} 11,13) ; 8.42(\mathrm{~m}, 1 \mathrm{H}, \mathrm{H} 6) ; 8.41(\mathrm{~m}, 1 \mathrm{H}, \mathrm{H} 4) ; 8.28(\mathrm{~m}$, $2 \mathrm{H}, \mathrm{H} 17,21) ; 8.25(\mathrm{~m}, 2 \mathrm{H} ; \mathrm{H} 10,14) ; 8.13(\mathrm{~d}, 1 \mathrm{H}, \mathrm{H} 3)$; 7.70(t, 1H, H5); 7.61(m, 3H, H18,19,20); 2.93(s, 3H; H15). ${ }^{13} \mathrm{C}$ NMR $\left(\mathrm{CDCl}_{3}, 200 \mathrm{MHz}, \mathrm{ppm}\right): \delta 169.41(\mathrm{C} 8)$; 150.06(C7); 146.32(C2,C12); 145.28(C6); 142.79(C4); 139.48(C16); 138.43(C9); 136.45(C17,21); 131.36(C19); 129.99(C18,20); 129.21(C11,13); 127.56(C10,14); 125.38(C5); 123.27(C3); 13.64(C15). ${ }^{119}$ Sn NMR $\left(\mathrm{CDCl}_{3}, 200 \mathrm{MHz}, \mathrm{ppm}\right): \delta-441.42$. Molar conductivity $\left(1 \times 10^{-3} \mathrm{~mol} \mathrm{~L}^{-1}, \mathrm{dmf}\right): 18.75 \Omega^{-1} \mathrm{~cm}^{2} \mathrm{~mol}^{-1}$. 


\section{$X$-ray crystallography}

Crystals of $\left[\mathrm{Bu}^{\mathrm{n}} \mathrm{Sn}(2 \mathrm{AcPh}) \mathrm{Cl}_{2}\right](\mathbf{1}),\left[\mathrm{Bu}^{\mathrm{n}} \mathrm{Sn}(2 \mathrm{Acp} \mathrm{ClPh})\right.$ $\left.\mathrm{Cl}_{2}\right]$ (2), $\left[\mathrm{Bu}^{\mathrm{n}} \mathrm{Sn}\left(2 \mathrm{Ac} p \mathrm{NO}_{2} \mathrm{Ph}\right) \mathrm{Cl}_{2}\right]\left(\right.$ 3), $\left[\mathrm{PhSn}(2 \mathrm{AcPh}) \mathrm{Cl}_{2}\right]$ (4) and $\left[\mathrm{PhSn}\left(2 \mathrm{Acp} \mathrm{NO}_{2} \mathrm{Ph}\right) \mathrm{Cl}_{2}\right] \cdot d \mathrm{dmso}(\mathbf{6 a})$ were mounted on glass fibers and used for data collection. X-ray diffraction data collection was performed on a Oxford-Diffraction GEMINI diffractometer (LabCri) using graphite-Enhance Source $\operatorname{MoK}_{\alpha}$ radiation $(\lambda=0.71069 \AA)$ at $293(2)$ K. Data integration and scaling of the reflections were performed with the Crysalis suite. ${ }^{34}$ Final unit cell parameters were based on the fitting of all reflections positions. The structures were solved by direct methods using the program SHELXS- $97^{35}$ and refined by full-matrix least-squares techniques against $\mathrm{F}^{2}$ using SHELXL-97. ${ }^{36}$ Positional and anisotropic atomic displacement parameters were refined for non hydrogen atoms, except for those involved in disorder systems for which isotropic ADP was used. Although some hydrogen atoms could be identified in a Fourier difference map, in the final model they were geometrically positioned and refined using a riding model. Criteria of a satisfactory complete analysis were the ratios of rms shift to standard deviation less than 0.001 and no significant features in final difference maps. Molecular graphics were obtained from ORTEP. ${ }^{37}$ A summary of the crystal's data, experimental details and refinement results are listed in Table 1.

\section{In vitro antimicrobial activity}

Antimicrobial activity was evaluated by minimum inhibitory concentration (MIC) using the macrodilution test. ${ }^{38}$ S. aureus ATCC6538 stored in Brain Heart Infusion

Table 1. Crystal data and refinement results for $\left[\mathrm{Bu}^{\mathrm{n}} \mathrm{Sn}(2 \mathrm{AcPh}) \mathrm{Cl}_{3}\right](\mathbf{1}),\left[\mathrm{Bu}^{\mathrm{n}} \mathrm{Sn}(2 \mathrm{Acp} \mathrm{ClPh}) \mathrm{Cl}_{3}\right](\mathbf{2}),\left[\mathrm{Bu}^{\mathrm{n}} \mathrm{Sn}\left(2 \mathrm{AcpNO}_{2} \mathrm{Ph}\right) \mathrm{Cl}_{3}\right](\mathbf{3}),\left[\mathrm{PhSn}(2 \mathrm{AcPh}) \mathrm{Cl} l_{3}\right](\mathbf{4})$ and $\left[\mathrm{PhSn}\left(2 \mathrm{AcpNO} \mathrm{Nh}_{2} \mathrm{Ph}\right) \mathrm{Cl}_{3}\right] \cdot d m s o(6 \mathbf{6})$

\begin{tabular}{|c|c|c|c|c|c|c|}
\hline \multicolumn{2}{|l|}{ Compound } & 1 & 2 & 3 & 4 & $6 a$ \\
\hline \multicolumn{2}{|l|}{ Empirical Formula } & $\mathrm{C}_{18} \mathrm{H}_{21} \mathrm{Cl}_{2} \mathrm{~N}_{3} \mathrm{OSn}$ & $\mathrm{C}_{18} \mathrm{H}_{20} \mathrm{Cl}_{3} \mathrm{~N}_{3} \mathrm{OSn}$ & $\mathrm{C}_{18} \mathrm{H}_{20} \mathrm{C}_{12} \mathrm{~N}_{4} \mathrm{O}_{3} \mathrm{Sn}$ & $\mathrm{C}_{20} \mathrm{H}_{17} \mathrm{C}_{12} \mathrm{~N}_{3} \mathrm{OSn}$ & $\mathrm{C}_{22} \mathrm{H}_{22} \mathrm{Cl}_{2} \mathrm{~N}_{4} \mathrm{O}_{4} \mathrm{SSn}$ \\
\hline \multicolumn{2}{|l|}{ Formula Weight } & 484.97 & 519.41 & 529.97 & 504.96 & 628.09 \\
\hline \multicolumn{2}{|l|}{ Crystal System } & orthorhombic & orthorhombic & triclinic & triclinic & monoclinic \\
\hline \multicolumn{2}{|l|}{ Space Group } & $F \mathrm{~d} \mathrm{~d} 2$ & $F \mathrm{~d} \mathrm{~d} 2$ & $P-1$ & $P-1$ & $P 2_{1} / c$ \\
\hline \multirow[t]{6}{*}{ Unit cell dimensions } & $a, \AA$ & $27.440(4)$ & $26.6226(17)$ & $12.9843(4)$ & $11.4662(3)$ & $14.4967(4)$ \\
\hline & $b, \AA$ & $22.024(4)$ & $23.9627(18)$ & $13.3554(6)$ & $12.5545(3)$ & $13.4617(4)$ \\
\hline & $c, \AA$ & $13.316(2)$ & $13.3438(7)$ & $14.1000(7)$ & $16.2705(4)$ & $13.3607(3)$ \\
\hline & $\alpha,^{o}$ & 90 & 90 & $111.487(4)$ & $112.147(2)$ & 90 \\
\hline & $\beta,{ }^{\circ}$ & 90 & 90 & $94.407(3)$ & $95.650(2)$ & $102.523(3)$ \\
\hline & $\gamma,{ }^{\circ}$ & 90 & 90 & $105.649(3)$ & $101.670(2)$ & 90 \\
\hline \multicolumn{2}{|l|}{ Volume, $\AA^{3}$} & $8047(2)$ & $8512.7(10)$ & $2148.31(16)$ & 2084.75(9) & $2545.31(12)$ \\
\hline \multicolumn{2}{|c|}{$\mathrm{Z} /$ Density calc., $\mathrm{Mg} / \mathrm{m}^{3}$} & $16 / 1.601$ & $16 / 1.621$ & $4 / 1.639$ & $4 / 1.609$ & 4 / 1.639 \\
\hline \multicolumn{2}{|c|}{ Absorption coefficient, $\mathrm{mm}^{-1}$} & 1.546 & 1.589 & 1.464 & 1.496 & 1.332 \\
\hline \multicolumn{2}{|l|}{$\mathrm{F}(000)$} & 3872 & 4128 & 1056 & 1000 & 1256 \\
\hline \multicolumn{2}{|l|}{ Crystal size, $\mathrm{mm}$} & $0.27 \times 0.24 \times 0.12$ & $0.29 \times 0.24 \times 0.18$ & $0.28 \times 0.25 \times 0.10$ & $0.24 \times 0.18 \times 0.09$ & $0.19 \times 0.19 \times 0.05$ \\
\hline \multicolumn{2}{|c|}{$\theta$ range for data collection, ${ }^{\circ}$} & 2.86 to 26.37 & 3.07 to 26.37 & 2.76 to 26.37 & 2.61 to 26.37 & 2.79 to 26.37 \\
\hline \multicolumn{2}{|l|}{ Index range, $\theta$} & $\begin{array}{l}-34 \leq h \leq 31 \\
-27 \leq k \leq 23 \\
-15 \leq l \leq 16\end{array}$ & $\begin{array}{l}-24 \leq h \leq 33 \\
-29 \leq k \leq 29 \\
-13 \leq l \leq 16\end{array}$ & $\begin{array}{l}-16 \leq h \leq 16 \\
-13 \leq k \leq 16 \\
-17 \leq l \leq 16\end{array}$ & $\begin{array}{l}-14 \leq h \leq 11 \\
-14 \leq k \leq 15 \\
-20 \leq l \leq 19\end{array}$ & $\begin{array}{l}-18 \leq h \leq 18 \\
-16 \leq k \leq 16 \\
-16 \leq l \leq 13\end{array}$ \\
\hline \multicolumn{2}{|c|}{ Completeness to $\theta=26.37^{\circ}$} & $99.9 \%$ & $99.6 \%$ & $99.9 \%$ & $99.9 \%$ & $99.9 \%$ \\
\hline \multicolumn{2}{|l|}{ Absorption correction } & none & none & none & none & none \\
\hline \multicolumn{2}{|l|}{ Goodness-of-fit on $F^{2}$} & 0.927 & 1.072 & 0.814 & 0.869 & 0.829 \\
\hline \multicolumn{2}{|c|}{ Reflections collected/unique $\left(R_{\text {int }}\right)$} & $\begin{array}{c}12047 / 3852 \\
(0.0647)\end{array}$ & $\begin{array}{c}6718 / 3555 \\
(0.0319)\end{array}$ & $\begin{array}{c}19702 / 8769 \\
(0.0474)\end{array}$ & $\begin{array}{c}18566 / 8525 \\
(0.0295)\end{array}$ & $\begin{array}{c}14702 / 5212 \\
(0.0447)\end{array}$ \\
\hline \multicolumn{2}{|c|}{ Absolute structure parameter } & $0.03(5)$ & $0.06(5)$ & - & - & - \\
\hline \multicolumn{2}{|c|}{ Data / restraints / parameters } & $3852 / 11 / 224$ & $3555 / 6 / 235$ & 8769 / 8 / 470 & $8525 / 0 / 487$ & $5212 / 0 / 307$ \\
\hline \multicolumn{2}{|c|}{ Observed reflections, $\mathrm{I}>2 \sigma(\mathrm{I})$} & 2232 & 2405 & 4288 & 5929 & 3261 \\
\hline \multicolumn{2}{|c|}{ Final $R$ indices $[\mathrm{I}>2 \sigma(\mathrm{I})]$} & $\begin{array}{c}R_{1}=0.0477 \\
w R_{2}=0.1077\end{array}$ & $\begin{array}{c}R_{1}=0.0483, \\
w R_{2}=0.1335\end{array}$ & $\begin{array}{c}R_{1}=0.0442, \\
w R_{2}=0.0963\end{array}$ & $\begin{array}{c}R_{1}=0.0257 \\
w R_{2}=0.0441\end{array}$ & $\begin{array}{c}R_{1}=0.0324 \\
w R_{2}=0.0543\end{array}$ \\
\hline \multicolumn{2}{|l|}{$R$ indices (all data) } & $\begin{array}{c}R_{1}=0.0879 \\
w R_{2}=0.1166\end{array}$ & $\begin{array}{c}R_{1}=0.0740 \\
w R_{2}=0.1460\end{array}$ & $\begin{array}{c}R_{1}=0.1028 \\
w R_{2}=0.1055\end{array}$ & $\begin{array}{c}R_{1}=0.0469 \\
w R_{2}=0.0463\end{array}$ & $\begin{array}{c}R_{1}=0.0655 \\
w R_{2}=0.0580\end{array}$ \\
\hline \multicolumn{2}{|c|}{ Larg. peak and hole, e $\AA^{-3}$} & $1.047 /-0.660$ & $0.739 /-1.179$ & $0.951 /-0.490$ & $0.309 /-0.279$ & $0.968 /-0.569$ \\
\hline
\end{tabular}


(BHI) broth were subcultured for testing in the same medium and grown at $37{ }^{\circ} \mathrm{C}$. Then the bacterial cells were suspended in BHI, according to Clinical and Laboratory Standards Institute (CLSI) guidelines, ${ }^{39}$ to produce a suspension of about $10^{5} \mathrm{CFU}$ (colony forming units) $\mathrm{mL}^{-1}$. C. albicans ATCC18804 stored in Sabouraud broth was sub-cultured for testing in the same medium and grown at $37^{\circ} \mathrm{C}$. Then the yeast cells were suspended according to the $\mathrm{McFarland}_{\text {protocol }}{ }^{39}$ in saline solution to produce a suspension of about $10^{3}$ cells $\mathrm{mL}^{-1}$.

For both the antibacterial and antifungal activity evaluations serial dilutions of the compounds, previously dissolved in dmso, were prepared in test tubes. A 24-h old inoculum $(100 \mu \mathrm{L})$ was added to each tube. The MIC, defined as the lowest concentration of the test compound which inhibits the visible growth after $20 \mathrm{~h}$, was determined after incubation at $37^{\circ} \mathrm{C}$. Tests using tetracycline (in the case of $S$. aureus) or fluconazole (in the case of $C$. albicans) as reference and dmso as negative control were carried out in parallel. The final dmso concentration never exceeded $1 \%$. In all cases no inhibition was observed with $5 \% \mathrm{v} / \mathrm{v}$ dmso. All tests were performed in triplicates with full agreement between the results.

\section{Results and Discussion}

Microanalyses and molar conductivity data suggest the formation of the following complexes: $\left[\mathrm{Bu}{ }^{n} \mathrm{Sn}(2 \mathrm{AcPh}) \mathrm{Cl}_{2}\right]$ (1), $\left[\mathrm{Bu}^{\mathrm{n}} \mathrm{Sn}(2 \mathrm{AcpClPh}) \mathrm{Cl}_{2}\right](\mathbf{2}),\left[\mathrm{Bu}^{\mathrm{n}} \mathrm{Sn}\left(2 \mathrm{Acp} \mathrm{NO}_{2} \mathrm{Ph}\right) \mathrm{Cl}_{2}\right]$ (3), $\left[\mathrm{PhSn}(2 \mathrm{AcPh}) \mathrm{Cl}_{2}\right]$ (4), $\left[\mathrm{PhSn}(2 \mathrm{Acp} \mathrm{ClPh}) \mathrm{Cl}_{2}\right]$ (5) and $\left[\mathrm{PhSn}\left(2 \mathrm{AcpNO} \mathrm{NO}_{2} \mathrm{Ph}\right) \mathrm{Cl}_{2}\right](\mathbf{6})$, in which an anionic hydrazone is attached to the metal centre along with a $n$-butyl or a phenyl group and the remaining coordination sites are occupied by two chloride ions. X-ray diffraction analysis confirms the structures of 1-4 and $\mathbf{6}$ (as its dmso solvate, $\left.\left[\mathrm{PhSn}\left(2 \mathrm{Acp} \mathrm{NO}_{2} \mathrm{Ph}\right) \mathrm{Cl}_{2}\right] \cdot \mathrm{dmso}, \mathbf{6 a}\right)$.

\section{Spectroscopic characterization}

\section{Infrared spectra}

The $v(\mathrm{~N}-\mathrm{H})$ and $v(\mathrm{C}=\mathrm{O})$ absorptions at $3180-3287 \mathrm{~cm}^{-1}$ and $1655-1676 \mathrm{~cm}^{-1}$ in the spectra of the uncomplexed hydrazones were not found in the spectra of complexes (1-6), in accordance with the presence of anionic ligands in the products.

The $v(\mathrm{C}=\mathrm{C})+v(\mathrm{C}=\mathrm{N})$ composed mode observed at $1590-1460 \mathrm{~cm}^{-1}$ in the spectra of the hydrazones undergoes small shifts in the spectra of the complexes. However a new $v(\mathrm{C}=\mathrm{N})$ absorption due to the formation of a second $\mathrm{C}=\mathrm{N}$ bond was observed at $1625-1632 \mathrm{~cm}^{-1}$ in the spectra of 1-6, indicating coordination of an anionic hydrazone.
The pyridine in-plane deformation mode at $620-625 \mathrm{~cm}^{-1}$ in the spectra of the hydrazones shifts to $647-650 \mathrm{~cm}^{-1}$ in those of the complexes, suggesting coordination of the heteroaromatic nitrogen..$^{29-31}$ In addition, new absorptions at $495-475 \mathrm{~cm}^{-1}$ and $450-350 \mathrm{~cm}^{-1}$ have been attributed to $v\left(\mathrm{Sn}-\mathrm{N}_{\text {imine }}\right)$ and $v(\mathrm{Sn}-\mathrm{C})$ respectively; absorptions at $230-215 \mathrm{~cm}^{-1}$ were assigned to $v\left(\mathrm{Sn}-\mathrm{N}_{\mathrm{py}}\right),{ }^{25,28,40}$ and bands in the 405-390 $\mathrm{cm}^{-1}$ range have been assigned to $v(\mathrm{Sn}-\mathrm{O})$. An absorption at $260-250 \mathrm{~cm}^{-1}$ has been attributed to $v(\mathrm{Sn}-\mathrm{Cl}){ }^{25,28,40}$ Therefore, the infrared data for the complexes indicate coordination of the hydrazones through the $\mathrm{N}_{\mathrm{py}}-\mathrm{N}-\mathrm{O}$ chelating system, as confirmed by the X-ray structure determinations for 1-4 and $\mathbf{6 a}$.

\section{NMR spectra}

The ${ }^{1} \mathrm{H}$ and ${ }^{13} \mathrm{C}$ NMR spectra of the hydrazones were recorded in dmso- $d_{6}$ as well as in $\mathrm{CDCl}_{3}$ except in the case of $\mathrm{H} 2 \mathrm{Ac} p \mathrm{NO}_{2} \mathrm{Ph}$, which is insoluble in $\mathrm{CDCl}_{3}$. The spectra of complexes 1-6 were recorded only in $\mathrm{CDCl}_{3}$ since some of them interact with dmso- $d_{6}$.

The ${ }^{1} \mathrm{H}$ resonances were assigned on the basis of chemical shifts, multiplicities and coupling constants. The carbon type $(\mathrm{C}, \mathrm{CH})$ was determined by using distortionless enhancement by polarization transfer (DEPT135) experiments. The assignments of the protonated carbons were made by $2 \mathrm{D}$ heteronuclear multiple quantum coherence experiments (HMQC). A ${ }^{119}$ Sn NMR study was performed for all complexes.

The NMR spectra of $\mathrm{H} 2 \mathrm{AcPh}$ in $\mathrm{CDCl}_{3}$ show only one signal for each hydrogen and each carbon, indicating the presence of only one configurational isomer. The signal of N3-H was observed at $\delta 9.22$, suggesting the presence of the $E$ isomer. The spectra recorded after $24 \mathrm{~h}$ do not show any changes. The spectra recorded in dmso- $d_{6}$ show two signals for each hydrogen and carbon, in accordance with the presence of the $E$ and $Z$ isomers (see Figure 1) in solution. ${ }^{29-31}$ The signals of $\mathrm{N} 3-\mathrm{H}$ at $\delta 10.90$ and $\delta 15.80$ were attributed to the $E$ and $Z$ isomers respectively (97\% of $E$ and $3 \%$ of $Z$ ). The high frequency signal of the $Z$ isomer is characteristic of $\mathrm{N} 3-\mathrm{H}$ hydrogen-bonded to the heteroaromatic nitrogen while the signal at $\delta 10.90$ is characteristic of N3-H hydrogen-bonded to the solvent, as previously observed by us. ${ }^{29-31}$

$\mathrm{H} 2 \mathrm{Ac} p \mathrm{NO}_{2} \mathrm{Ph}$ is soluble in dmso- $d_{6}$ but insoluble in $\mathrm{CDCl}_{3}$. In the ${ }^{1} \mathrm{H}$ and ${ }^{13} \mathrm{C}$ NMR spectra (dmso- $d_{6}$ ) of $\mathrm{H} 2 \mathrm{Ac} p \mathrm{NO}_{2} \mathrm{Ph}$ only one signal has been observed for each hydrogen and each carbon. The signal of N3-H was found at $\delta 11.22$, suggesting the presence of the $E$ configurational isomer, in which N3-H is hydrogen-bonded to the solvent. ${ }^{29-31}$ 
The ${ }^{1} \mathrm{H}$ and ${ }^{13} \mathrm{C}$ NMR spectra of $\mathrm{H} 2 \mathrm{Acp} \mathrm{ClPh}$ in dmso- $d_{6}$ show duplicated signals for the hydrogens, in accordance with the presence of two configurational isomers. The signals of $\mathrm{N} 3-\mathrm{H}$ at $\delta 10.96$ and $\delta 15.86$ were attributed to the $E(98 \%)$ and $Z(2 \%)$ isomers, respectively. ${ }^{29-31}$ Due to the low solubility of $\mathrm{H} 2 \mathrm{Ac} p \mathrm{ClPh}$ in dmso- $d_{6}$ only some of the signals of hydrogens could be attributed and no attribution was possible for the carbons of the $Z$ isomer.

The spectra of this compound in $\mathrm{CDCl}_{3}$ also show duplicated signals. However in this case the spectra are characteristic of the presence of the keto and enol forms. ${ }^{41}$ In fact no signal of N3-H was observed for the first isomer, according to the presence of the enol form. In addition, the signal of C-O was observed at $\delta 167.44$. The resemblance in position of the carbon signals of $\mathrm{H} 2 \mathrm{Acp} \mathrm{ClPh}$ with those of $\mathrm{H} 2 \mathrm{AcPh}$ in the same solvent suggests that the enol isomer adopts the $E$ configuration. As an example, the signal of $\mathrm{C} 15$ (acetyl) was observed at $\delta 11.36$, close to the signal for the same hydrogen at $\delta 10.89$ observed for the $E$ isomer of $\mathrm{H} 2 \mathrm{AcPh}$ in $\mathrm{CDCl}_{3}$. The keto isomer exhibits the signal of N3-H at $\delta 15.83$, characteristic of the $Z$ configuration, and the signal of $\mathrm{C}=\mathrm{O}$ at $\delta 163.40$.

Only one signal was observed for each hydrogen and each carbon in the spectra of complexes 1-6, suggesting the presence of only one configurational isomer. The signals of $\mathrm{C}=\mathrm{N}, \mathrm{C}=\mathrm{O}$ and the pyridine carbons undergo significant shifts in the complexes indicating coordination through the
$\mathrm{N}_{\mathrm{py}}-\mathrm{N}-\mathrm{O}$ chelating system. Hence the hydrazones adopt the $E$ configuration in the complexes, as confirmed by crystal structure determinations of complexes 1-4 and $\mathbf{6 a}$. Moreover, the signal of N3-H was not observed in the ${ }^{1} \mathrm{H}$ NMR spectra of the complexes, according to deprotonation of the hydrazones upon coordination.

In the spectra of complexes 1-3, new signals at $\delta 2.35$ 1.05 and at $\delta 35.80-13.60$ were attributed to the hydrogens and carbons, respectively, of the $n$-butyl group attached to the metal..$^{28}$ In the spectra of complexes 4-6, the signals at $\delta 8.33-7.59$ and at $\delta 136.62-129.08$ were attributed to the hydrogens and carbons, respectively, of the phenyl group coordinated to tin. ${ }^{40}$

In the ${ }^{119} \mathrm{Sn}$ NMR spectra of complexes 1-6 $\left(\mathrm{CDCl}_{3}\right)$ only one signal was observed at $\delta-414(\mathbf{1}), \delta-413$ (2), $\delta-412(3), \delta-443(4), \delta-442(5)$ and $\delta-441(6) \mathrm{ppm}$, compatible with the presence of one tin site in solution. The values of the ${ }^{119} \mathrm{Sn}$ signals are at the boundary between six- and seven-coordinated tin(IV) as reported in the literature..$^{42}$ However, considering that the spectra were recorded in a non-coordinating solvent $\left(\mathrm{CDCl}_{3}\right)$, only six-coordinated species must be present in solution. The shielding effect on ${ }^{119} \mathrm{Sn}$ of the chloride ions could explain the lower frequencies observed for the ${ }^{119} \mathrm{Sn}$ signals with respect to that expected for a six-coordinated monorganotin(IV). ${ }^{42}$
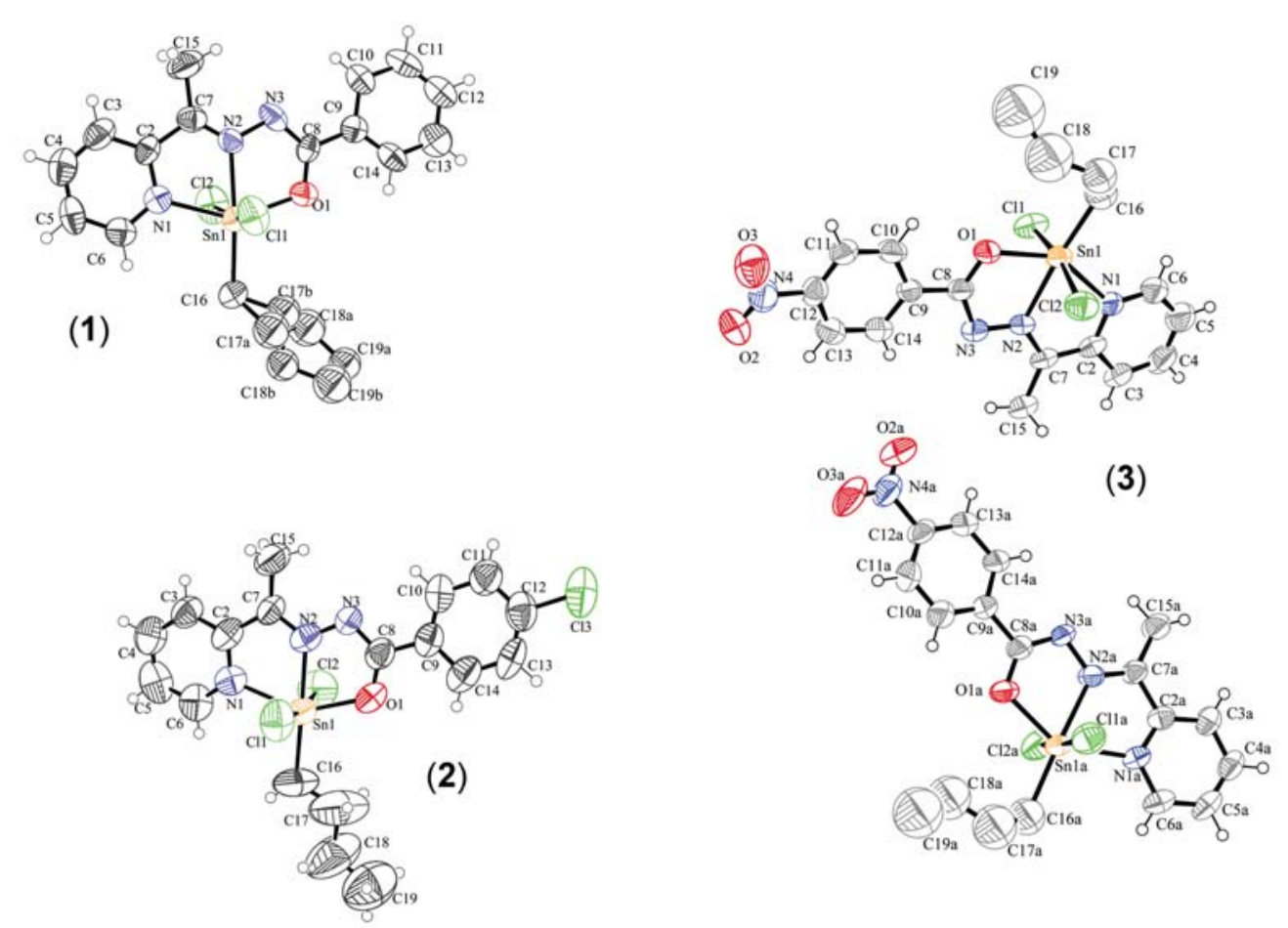

Figure 2. Molecular plot of the asymmetric units of $\left[\left(\mathrm{Bu}^{\mathrm{n}}\right) \mathrm{Sn}(2 \mathrm{AcPh}) \mathrm{Cl}_{2}\right](\mathbf{1}),\left[\left(\mathrm{Bu}^{\mathrm{n}}\right) \operatorname{Sn}(2 \mathrm{Acp} \mathrm{ClPh}) \mathrm{Cl}_{2}\right](\mathbf{2})$ and $\left[\left(\mathrm{Bu}^{\mathrm{n}}\right) \operatorname{Sn}\left(2 \mathrm{AcpNO}_{2} \mathrm{Ph}\right) \mathrm{Cl}_{2}\right](\mathbf{3}) \operatorname{showing}$ the labeling scheme of the non-H atoms and their displacement ellipsoids at the $50 \%$ probability level. 

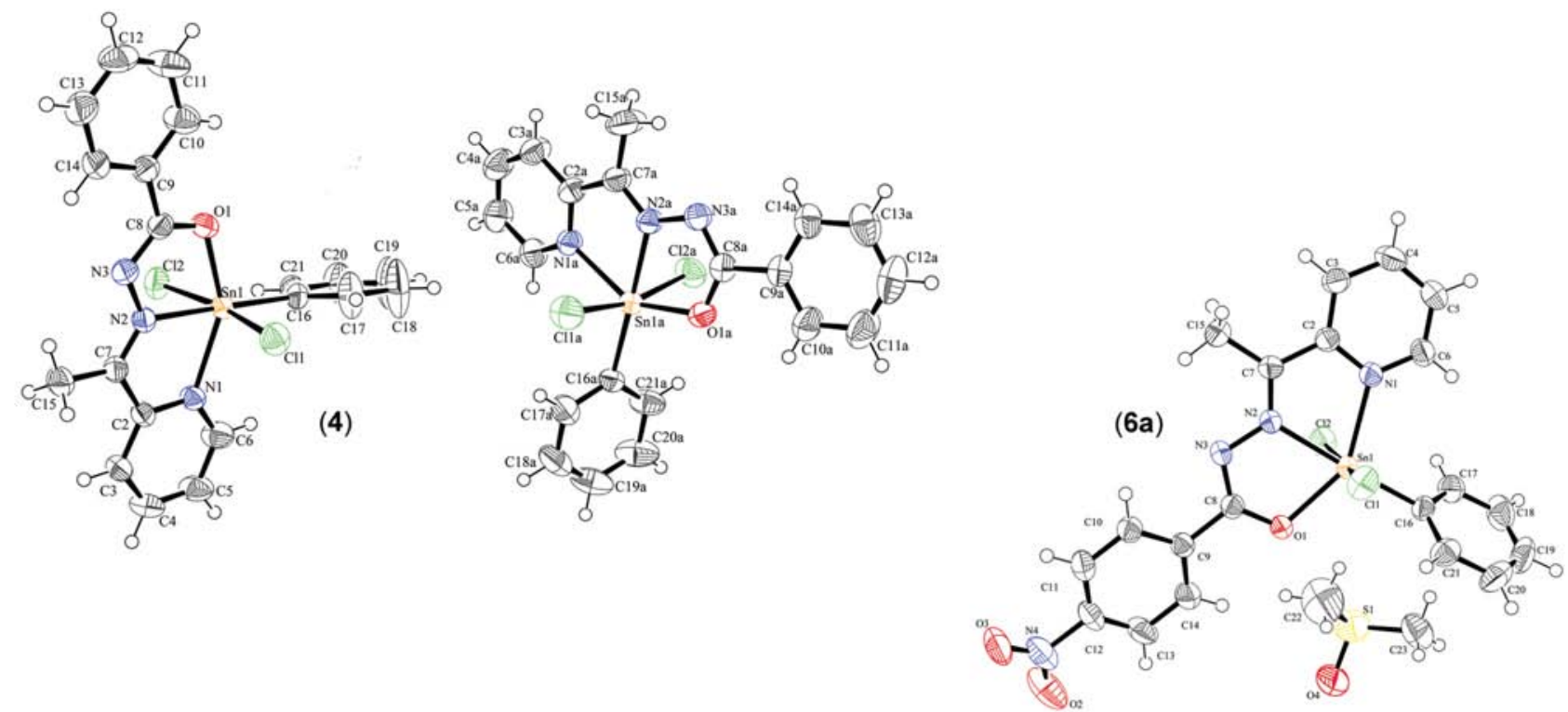

Figure 3. Molecular plot of the asymmetric units of $\left[\mathrm{PhSn}(2 \mathrm{AcPh}) \mathrm{Cl}_{2}\right](4)$ and $\left[\mathrm{PhSn}\left(2 \mathrm{AcpNO}_{2} \mathrm{Ph}_{2} \mathrm{Cl}_{2}\right] \cdot \mathrm{dmso}(\mathbf{6 a})\right.$ showing the labeling scheme of the non- $\mathrm{H}$ atoms and their displacement ellipsoids at the $50 \%$ probability level.

\section{$X$-ray diffraction analysis}

Figures 2 and 3 are perspective views of $\left[\mathrm{Bu}^{\mathrm{n}} \mathrm{Sn}(2 \mathrm{AcPh}) \mathrm{Cl}_{2}\right]$ (1), $\left[\mathrm{Bu}{ }^{n} \mathrm{Sn}(2 \mathrm{Acp} \mathrm{ClPh}) \mathrm{Cl}_{2}\right](\mathbf{2}),\left[\mathrm{Bu}^{\mathrm{n}} \mathrm{Sn}\left(2 \mathrm{Ac} p \mathrm{NO}_{2} \mathrm{Ph}\right) \mathrm{Cl}_{2}\right]$ (3), $\left[\mathrm{PhSn}(2 \mathrm{AcPh}) \mathrm{Cl}_{2}\right](4)$ and $\left[\mathrm{PhSn}\left(2 \mathrm{Acp} \mathrm{NO}_{2} \mathrm{Ph}\right) \mathrm{Cl}_{2}\right] \cdot \mathrm{dmso}$ (6a). Selected intramolecular bond distances and angles of the complexes are given in Tables 2 and 3. The distances and angles in all complexes are similar. In all complexes tin(IV) is coordinated to a tridentate anionic ligand, a $n$-butyl (1-3) or a phenyl (4 and 6a) group and two chloride ions trans to each other in an distorted octahedral environment. In the crystal structures of $\mathbf{3}$ and $\mathbf{4}$, two symmetrically independent molecules were found in the asymmetric unit (see Figure 2 and Figure 3).

In complexes 1-4 and 6a the N1-Sn-O1 angle of $c a$. $144.3-146.7^{\circ}$ deviates markedly from the ideal value of $180^{\circ}$, probably due to the spatial requirements of the ligand chelating system. By contrast, the $\mathrm{Cl} 1-\mathrm{Sn}-\mathrm{Cl} 2$ and N2-Sn-C16 angles, which do not involve sterical hindrance, are approximately $167.3-171.4^{\circ}$ and $172.5-179.1^{\circ}$ (see Table 3). In all complexes the metal atom lies in the plane calculated for the N1N2O1C16 atoms. In structures 1-3 the distance of the tin atom to the calculated plane varies from $0.023 \AA$ to $0.059 \AA$; in structures $\mathbf{4}$ and $\mathbf{6 a}$ this distance is smaller ( 0.002 to $0.009 \AA)$.

In all structures the hydrazone skeleton $(\mathrm{C} 7(\mathrm{C} 15)$ $\mathrm{N} 2 \mathrm{~N} 3 \mathrm{C} 8 \mathrm{O} 1$ ) is planar, with medium deviation of the fitted atoms from the calculated plane ranging from 0.0055 to $0.0266 \AA$. In 1-4 and $\mathbf{6 a}$ the hydrazone adopts the $E$ configuration in relation to the $\mathrm{C} 7=\mathrm{N} 2$ double bond. The angle between the pyridine and the hydrazone planes varies from $1.5(6)$ to $7.5(3)^{\circ}$, while the angle between the hydrazone and the phenyl planes varies in the 0.5(2) to $14.9(2)^{\circ}$ range. Therefore the hydrazone ligand in all complexes is almost planar. Complexes $\mathbf{3}$ and $\mathbf{6 a}$ show the highest deviation from planarity for the angle between the hydrazone chain and the phenyl ring.

The molecular structure of $\mathrm{H} 2 \mathrm{AcPh}$ has been determined previously by other authors. ${ }^{43}$ The hydrazone adopts the $E Z$ conformation in relation to the $\mathrm{C} 7=\mathrm{N} 2$ and N3-C8 bonds. The expected lengthening of the $\mathrm{C} 8-\mathrm{O} 1$ bonds from $1.219(2) \AA$ in $\mathrm{H}_{2} \mathrm{AcPh}^{43}$ to $1.279(11) \AA$ in $\mathbf{1}$ and $1.292(3)$ and $1.302(3) \AA$ in $\mathbf{4}$, together with the shortening of the N3-C8 bond from 1.347(3) $\AA$ in $\mathrm{H} 2 \mathrm{AcPh}^{43}$ to 1.337(12) $\AA$ in $\mathbf{1}$ and 1.321(3) and 1.327(3) $\AA$ in 4 , were observed (see Table 2). Therefore the C8-O1 bond changes from a double to a predominantly single bond whereas N3-C8 acquires some double bond character. The bond distances between tin and the imine nitrogen in the complexes, 2.184(4)-2.161(7) $\AA$, are slightly shorter than the distance between tin and the pyridine nitrogen, 2.288(4)-2.2354(18) $\AA$. The Sn-O bond lengths lie in the 2.0916(17)-2.108(3) ̊ range.

Bond distances in the five complexes are similar to those found in other tin(IV) complexes with hydrazones, as in trans-dimethyl[2,6-diacetylpyridinebis(2-theoylhydrazone)] $\operatorname{tin}(\mathrm{IV})^{44}$, where N3-C8 and C8-O1 bond distances of $1.322(8) \AA$ and 1.286(7) $\AA$, respectively, and $\mathrm{Sn}-\mathrm{C}, \mathrm{Sn}-\mathrm{N}_{\mathrm{py}}$, $\mathrm{Sn}-\mathrm{N}_{\text {imine }}$ and $\mathrm{Sn}-\mathrm{O}$ bond distances of 2.102(6), 2.327(4), 2.255(5) and 2.209(4) A, respectively, were observed. 
A twisting of approximately $180^{\circ}$ in the $\mathrm{C} 2-\mathrm{C} 7$ bond of the hydrazone to match the steric requirements of tridentate coordination was evidenced. Hence some angles undergo significant changes on complexation. The C8-N3-N2 angle goes from $117.02(13)^{\circ}$ in $\mathrm{H}_{2} \mathrm{AcPh}^{43}$ to $110.7(7)^{\circ}$ in $\mathbf{1}$ and to $109.5(2)^{\circ}$ and $109.8(2)^{\circ}$ in $\mathbf{4}$; N3-C8-O goes from $123.32(15)^{\circ}$ in the free base ${ }^{43}$ to $125.7(8)^{\circ}$ in $\mathbf{1}$ and to $126.4(2)^{\circ}$ and $125.2(2)^{\circ}$ in $\mathbf{4}$.

The molecular packings of all complexes show weak interactions involving $\mathrm{Cl}, \mathrm{H}$ and $\mathrm{O}$ atoms with formation of molecular chains as shown in Figure 4. 1-4 show interactions between adjacent molecules involving $\mathrm{Cl} \cdots \mathrm{H}_{\mathrm{py}}$. In $\mathbf{4}$ and $\mathbf{6 a}$ short $\mathrm{Cl} \cdots \mathrm{H}$ contacts are observed involving chlorides and hydrogens from the hydrazone phenyl ring. In $\mathbf{6 a} \mathrm{Cl} \cdots \mathrm{H}$ interactions were observed as well, along with short $\mathrm{H} \cdots \mathrm{O}$ contacts involving the oxygens from dmso and from the nitro group and hydrogens from pyridine and dmso.

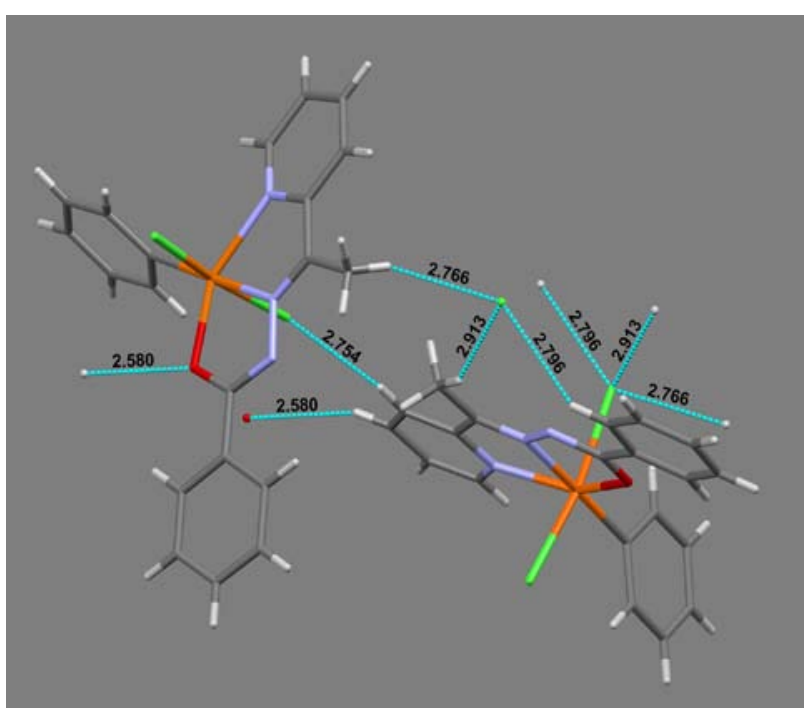

Figure 4. Molecular structure scheme of $\left[\mathrm{PhSn}(2 \mathrm{AcPh}) \mathrm{Cl}_{2}\right]$ (4) showing short intermolecular contacts between $\mathrm{Cl} \cdots \mathrm{H}$ and $\mathrm{O} \cdots \mathrm{H}$ atoms.

Table 2. Selected bond lengths ( $\mathrm{A})$ for $\left[\mathrm{Bu}^{\mathrm{n}} \mathrm{Sn}(2 \mathrm{AcPh}) \mathrm{Cl}_{2}\right](\mathbf{1}),\left[\mathrm{Bu}^{\mathrm{n}} \mathrm{Sn}(2 \mathrm{AcpClPh}) \mathrm{Cl}_{2}\right](\mathbf{2}),\left[\mathrm{Bu}^{\mathrm{n}} \mathrm{Sn}\left(2 \mathrm{AcpNO} \mathrm{Ph}_{2} \mathrm{Cl}_{2}\right](\mathbf{3}),\left[\mathrm{PhSn}(2 \mathrm{AcPh}) \mathrm{Cl} l_{2}\right](\mathbf{4})\right.$ and $\left[\mathrm{PhSn}\left(2 \mathrm{Acp} \mathrm{NO}_{2} \mathrm{Ph}\right) \mathrm{Cl}_{2}\right] \cdot \mathrm{dmso}(\mathbf{6 a})$

\begin{tabular}{|c|c|c|c|c|c|c|c|}
\hline Bond & 1 & 2 & & & & & $6 a$ \\
\hline $\mathrm{C} 2-\mathrm{C} 7$ & $1.495(11)$ & $1.504(13)$ & $1.456(7)$ & $1.483(7)$ & $1.487(3)$ & $1.467(4)$ & $1.478(4)$ \\
\hline C7-C15 & $1.505(12)$ & $1.474(12)$ & $1.484(7)$ & $1.474(7)$ & $1.479(3)$ & $1.486(3)$ & $1.479(4)$ \\
\hline $\mathrm{C} 7-\mathrm{N} 2$ & $1.253(11)$ & $1.298(10)$ & $1.283(6)$ & $1.279(6)$ & $1.285(3)$ & $1.285(3)$ & $1.282(4)$ \\
\hline $\mathrm{N} 2-\mathrm{N} 3$ & $1.381(9)$ & $1.363(10)$ & $1.381(6)$ & $1.390(5)$ & $1.381(2)$ & $1.369(3)$ & $1.375(3)$ \\
\hline $\mathrm{N} 3-\mathrm{C} 8$ & $1.337(12)$ & $1.305(11)$ & $1.346(6)$ & $1.308(7)$ & $1.321(3)$ & $1.327(3)$ & $1.313(4)$ \\
\hline $\mathrm{C} 8-\mathrm{C} 9$ & $1.455(12)$ & $1.475(13)$ & $1.471(7)$ & $1.480(7)$ & $1.490(3)$ & $1.470(3)$ & $1.487(4)$ \\
\hline $\mathrm{C} 8-\mathrm{O} 1$ & $1.279(11)$ & $1.309(11)$ & $1.275(6)$ & $1.305(6)$ & $1.292(3)$ & $1.302(3)$ & $1.293(3)$ \\
\hline Sn1-O1 & $2.108(6)$ & $2.105(7)$ & $2.096(4)$ & $2.108(3)$ & $2.0996(14)$ & $2.0916(17)$ & $2.104(2)$ \\
\hline Sn1-N1 & $2.246(8)$ & $2.280(8)$ & $2.278(4)$ & $2.288(4)$ & $2.2354(18)$ & $2.2484(19)$ & $2.264(3)$ \\
\hline Sn1-N2 & $2.171(7)$ & $2.161(7)$ & $2.184(4)$ & $2.175(4)$ & $2.165(2)$ & $2.1713(18)$ & $2.170(3)$ \\
\hline Sn1-C11 & $2.456(2)$ & $2.460(2)$ & $2.445(2)$ & $2.445(2)$ & $2.4584(7)$ & $2.4705(7)$ & $2.4771(9)$ \\
\hline $\mathrm{Sn} 1-\mathrm{Cl} 2$ & $2.494(3)$ & $2.455(3)$ & $2.500(2)$ & $2.473(2)$ & $2.4532(7)$ & $2.4471(7)$ & $2.4452(9)$ \\
\hline Sn1-C16 & $2.119(9)$ & $2.166(12)$ & $2.140(7)$ & $2.137(8)$ & $2.138(3)$ & $2.124(2)$ & $2.135(3)$ \\
\hline
\end{tabular}

Table 3. Selected angles $\left(^{\circ}\right)$ for $\left[\mathrm{Bu}^{\mathrm{n}} \mathrm{Sn}(2 \mathrm{AcPh}) \mathrm{Cl}_{2}\right](\mathbf{1}),\left[\mathrm{Bu}^{\mathrm{n}} \mathrm{Sn}(2 \mathrm{AcpClPh}) \mathrm{Cl}_{2}\right](\mathbf{2}),\left[\mathrm{Bu}^{\mathrm{n}} \mathrm{Sn}\left(2 \mathrm{AcpNO}_{2} \mathrm{Ph}\right) \mathrm{Cl}_{2}\right](\mathbf{3}),\left[\mathrm{PhSn}(2 \mathrm{AcPh}) \mathrm{Cl}{ }_{2}\right](\mathbf{4})$ and $\left[\mathrm{PhSn}\left(2 \mathrm{Acp} \mathrm{NO}_{2} \mathrm{Ph}\right) \mathrm{Cl}_{2}\right] \cdot \mathrm{dmso}(\mathbf{6 a})$

\begin{tabular}{lccccccc}
\hline Angle & $\mathbf{1}$ & $\mathbf{2}$ & \multicolumn{2}{c}{$\mathbf{3}$} & & $\mathbf{4}$ & $\mathbf{6 a}$ \\
\hline C2-C7-N2 & $116.4(7)$ & $114.1(8)$ & $114.5(5)$ & $113.6(5)$ & $114.0(2)$ & $115.0(2)$ & $114.7(3)$ \\
N2-C7-C15 & $125.7(8)$ & $123.9(8)$ & $123.4(5)$ & $124.6(5)$ & $124.0(2)$ & $122.5(2)$ & $123.6(3)$ \\
C7-N2-N3 & $123.0(7)$ & $120.2(7)$ & $121.5(4)$ & $119.7(4)$ & $121.5(2)$ & $122.2(2)$ & $121.7(3)$ \\
C8-N3-N2 & $110.7(7)$ & $111.2(7)$ & $109.6(4)$ & $109.3(4)$ & $109.5(2)$ & $109.8(2)$ & $110.1(3)$ \\
N3-C8-C9 & $116.6(9)$ & $117.2(9)$ & $115.5(5)$ & $115.5(5)$ & $116.0(2)$ & $117.6(2)$ & $115.9(3)$ \\
N3-C8-O1 & $125.7(8)$ & $124.0(8)$ & $125.5(5)$ & $127.1(5)$ & $126.4(2)$ & $125.2(2)$ & $126.5(3)$ \\
C9-C8-O1 & $117.6(8)$ & $118.8(8)$ & $119.0(4)$ & $117.3(5)$ & $117.7(2)$ & $117.6(2)$ & $117.6(3)$ \\
N2-Sn1-C16 & $175.5(3)$ & $176.1(5)$ & $174.7(2)$ & $172.5(2)$ & $179.06(8)$ & $178.82(9)$ & $176.71(11)$ \\
N1-Sn1-O1 & $146.7(2)$ & $145.3(3)$ & $144.96(16)$ & $144.32(15)$ & $146.12(7)$ & $145.88(6)$ & $145.97(9)$ \\
Cl1-Sn1-C12 & $167.76(12)$ & $169.41(13)$ & $168.97(5)$ & $171.36(6)$ & $169.54(2)$ & $167.30(2)$ & $170.75(3)$ \\
\hline
\end{tabular}




\section{Antimicrobial activity}

The minimum inhibitory concentrations (MICs) of the hydrazones and their organotin complexes against S. aureus and C. albicans are reported in Table 4. Among the hydrazones the antibacterial activity follows the order $\mathrm{H} 2 \mathrm{AcPh}<\mathrm{H} 2 \mathrm{Acp} \mathrm{NO}_{2} \mathrm{Ph}<\mathrm{H} 2 \mathrm{Ac} p \mathrm{ClPh}$, suggesting that the electron-withdrawing effect of the nitro and chloro groups probably favors the antibacterial effect. The calculated values of $\log \mathrm{P}^{45}$ were: 1.98 for $\mathrm{H} 2 \mathrm{AcPh}, 2.58$ for $\mathrm{H} 2 \mathrm{Ac} p \mathrm{ClPh}$ and 1.92 for $\mathrm{H} 2 \mathrm{Ac} p \mathrm{NO}_{2} \mathrm{Ph}$. Therefore the higher lipophilicity of $\mathrm{H} 2 \mathrm{Ac} p \mathrm{ClPh}$ probably accounts in part for its higher activity.

Table 4. Minimum inhibitory concentrations (MIC) of the hydrazones and their organotin complexes against Staphylococcus aureus and Candida albicans

\begin{tabular}{|c|c|c|}
\hline Compound & $\begin{array}{c}\mathrm{MIC} /\left(\mu \mathrm{mol} \mathrm{mL}^{-1}\right) \\
\text { C. albicans }\end{array}$ & $\begin{array}{c}\mathrm{MIC} /\left(\mu \mathrm{mol} \mathrm{mL}^{-1}\right) \\
\text { S. aureus }\end{array}$ \\
\hline $\mathrm{H} 2 \mathrm{AcPh}$ & 0.213 & 0.428 \\
\hline$\left[\mathrm{Bu}^{\mathrm{n}} \mathrm{Sn}(2 \mathrm{AcPh}) \mathrm{Cl}_{2}\right](\mathbf{1})$ & 0.210 & 0.255 \\
\hline$\left[\mathrm{PhSn}(2 \mathrm{AcPh}) \mathrm{Cl}_{2}\right](4)$ & 0.206 & 0.132 \\
\hline $\mathrm{H} 2 \mathrm{Ac} p \mathrm{ClPh}$ & 0.046 & 0.197 \\
\hline$\left[\mathrm{Bu}^{\mathrm{n}} \mathrm{Sn}(2 \mathrm{Ac} p \mathrm{ClPh}) \mathrm{Cl}_{2}\right]$ & 0.045 & 0.059 \\
\hline$\left[\mathrm{PhSn}(2 \mathrm{Ac} p \mathrm{ClPh}) \mathrm{Cl}_{2}\right](\mathbf{5})$ & 0.046 & 0.057 \\
\hline $\mathrm{H} 2 \mathrm{Ac}_{\mathrm{NO}} \mathrm{NO}_{2} \mathrm{Ph}$ & $>0.179$ & 0.353 \\
\hline$\left[\mathrm{Bu}^{\mathrm{n}} \mathrm{Sn}\left(2 \mathrm{Ac} p \mathrm{NO}_{2} \mathrm{Ph}\right) \mathrm{Cl}_{2}\right]$ (3) & 0.096 & 0.125 \\
\hline$\left[\mathrm{PhSn}\left(2 \mathrm{Ac} p \mathrm{NO}_{2} \mathrm{Ph}\right) \mathrm{Cl}_{2}\right](\mathbf{6})$ & 0.093 & 0.114 \\
\hline$\left[\mathrm{Bu}^{\mathrm{n}} \mathrm{SnCl}_{3}\right]$ & $>0.86$ & $>1.88$ \\
\hline$\left[\mathrm{PhSnCl}_{3}\right]$ & 0.158 & 0.249 \\
\hline Tetracycline & - & 0.020 \\
\hline Fluconazole & 0.033 & - \\
\hline
\end{tabular}

$\left[\mathrm{Bu}^{\mathrm{n}} \mathrm{SnCl}_{3}\right]$ proved to be inactive against $S$. aureus while $\left[\mathrm{PhSnCl}_{3}\right]$ exhibited antibacterial activity in the assayed concentrations. The hydrazones showed antibacterial activity with MIC values similar to the phenyltin salt. Upon coordination the antibacterial activities of both the hydrazones and tin substantially increase. A synergistic effect involving tin and the hydrazone might be responsible for this enhancement.

The complex of $\mathrm{H} 2 \mathrm{AcPh}$ with phenyltin is more active than its $n$-butyltin analogue, but the $n$-butyltin and phenyltin complexes with the other two hydrazones are equally active. The activities of the $n$-butyltin complexes with the different hydrazones follows the order $\left[\mathrm{Bu}^{\mathrm{n}} \mathrm{Sn}(2 \mathrm{AcPh}) \mathrm{Cl}_{2}\right]<\left[\mathrm{Bu}^{\mathrm{n}} \mathrm{Sn}\left(2 \mathrm{Ac} p \mathrm{NO}_{2} \mathrm{Ph}\right) \mathrm{Cl}_{2}\right]<$ $\left[\mathrm{Bu}^{\mathrm{n}} \mathrm{Sn}(2 \mathrm{Acp} \mathrm{ClPh}) \mathrm{Cl}_{2}\right]$, which is the same order of activity of the free hydrazones. However, the activities of the phenyltin complexes are $\left[\mathrm{PhSn}(2 \mathrm{AcPh}) \mathrm{Cl}_{2}\right]=$
$\left[\mathrm{PhSn}\left(2 \mathrm{Ac} p \mathrm{NO}_{2} \mathrm{Ph}\right) \mathrm{Cl}_{2}\right]<\left[\mathrm{PhSn}(2 \mathrm{Ac} p \mathrm{ClPh}) \mathrm{Cl}_{2}\right]$. The most active complexes were those with $\mathrm{H} 2 \mathrm{Ac} p \mathrm{ClPh}$ (2 and 5), with MIC values similar to that determined for tetracycline.

Among the hydrazones $\mathrm{H} 2 \mathrm{Acp} \mathrm{ClPh}$ exhibited the highest activity against $C$. albicans. Upon coordination the antifungal activity of the hydrazones increased in complexes $\mathbf{3}$ and $\mathbf{6}$, but remained the same in the other cases. The antifungal activity increased in complexes $\mathbf{2}, \mathbf{3}$, 5 and $\mathbf{6}$ relative to the organotin salts.

Like in the case of the antibacterial activity, the best results were obtained for the organotin complexes with $\mathrm{H} 2 \mathrm{Ac} p \mathrm{ClPh}$. The MIC values for complexes 2 and $\mathbf{5}$ $\left(0.045 \mu \mathrm{mol} \mathrm{mL}^{-1}\right)$ were the same, suggesting that the $n$-butyl or the phenyl group in the metal coordination sphere have the same effect. This value of MIC is of the same order of magnitude of that obtained for fluconazole. Likewise, the MIC values are the same for complexes 3 and $\mathbf{6}$.

\section{Conclusions}

Organotin compounds are known for their innumerous bioactivities but are also often rather toxic. ${ }^{46,47}$ Coordination of organotin salts with organic ligands could be an interesting strategy for activity improvement ${ }^{48}$ or toxicity reduction. In the present work we demonstrated that coordination of organotin salts to hydrazones might improve the pharmacological profile of both metal and ligands. ${ }^{49}$

\section{Supplementary Information}

Crystallographic data have been deposited with the Cambridge Crystallographic Data Centre (deposition numbers CCDC 747621 (1), CCDC 747620 (2), CCDC 747624 (3), CCDC 747623 (4) and CCDC 747622 (6a)). Copies of available material can be obtained by request to CCDC, 12 Union Road, Cambridge CB2 1EZ, UK (fax 44-1223-336033 or e-mail: deposit@ccdc.cam.ac.uk).

\section{Acknowledgments}

This work was supported by FAPEMIG, CNPq and Instituto do Milênio em Inovação e Desenvolvimento de Novos Fármacos e Medicamentos (IM-INOFAR) (Proc. CNPq 573.564/2008-6), Brazil.

\section{References}

1. Vicini, P.; Zani, F.; Cozzini, P.; Doytchinova, I.; Eur. J. Med. Chem. 2002, 37, 553. 
2. Kocyigit-Kaymakcioglu, B.; Rollas, S.; Farmaco 2002, 57, 595.

3. Ragavendran, J. V.; Sriram, D.; Patel, S. K.; Reddy, I. V.; Bharathwajan, N.; Stables, J.; Yogeeswari, P.; Eur. J. Med. Chem. 2007, 42, 146.

4. Bezerra-Netto, H. J. C.; Lacerda, D. I.; Miranda, A. L. P.; Alves, H. M.; Barreiro, E. J.; Fraga, C. A. M.; Bioorg. Med. Chem. 2006, 4, 7924.

5. Avaji, P. G.; Kumar, C. H. V.; Patil, S. A.; Shivananda, K. N.; Nagaraju, C.; Eur. J. Med. Chem. 2009, 44, 3552.

6. Kümmerle, A. E.; Raimundo, J. M.; Leal, C. M.; Da Silva, G. S.; Balliano, T. L.; Pereira, M. A.; De Simone, C. A.; Sudo, R. T.; Zapata-Sudo, G.; Fraga, C. A. M.; Barreiro, E. J.; Eur. J. Med. Chem. 2009, 44, 4004.

7. Coelho, P. M. Z.; Pereira, L. H.; Rev. Inst. Med. Trop. São Paulo 1991, 33, 50.

8. Romeiro, N. C.; Aguirre, G.; Hernández, P.; González, M.; Cerecetto, H.; Aldana, I.; Pérez-Silanes, S.; Monge, A.; Barreiro, E. J.; Lima, L. M.; Bioorg. Med. Chem. 2009, 17, 641.

9. Stadler, A.; Harrowfield, J.; Inorg. Chim. Acta 2009, 362, 4298.

10. Pinto, J. J.; Moreno, C.; García-Vargas, M.; Talanta 2004, 64, 562.

11. Terra, L. H. S. A.; Guekezian, M.; Gaubeur, I.; Matos, J. R.; Suárez-Iha, M. E. V.; Polyhedron 2002, 21, 2375.

12. Pouralimardan, O.; Chamayou, A. C.; Janiak, C.; HosseiniMonfared, H.; Inorg. Chim. Acta 2007, 360, 1599.

13. Basu, C.; Chowdhury, S.; Banerjee, R.; Evans, H. S.; Mukherjee, S.; Polyhedron 2007, 26, 3617.

14. Bakir, M.; Green, O.; Mulder, W. H.; J. Mol. Struct. 2008, 17, 873.

15. Bacchi, A.; Carcelli, M.; Pelagatti, P.; Pelizzi, C.; Pelizzi, G.; Zani, F.; J. Inorg. Biochem. 1999, 9, 133.

16. Carcelli, M.; Mazza, P.; Pelizi, C.; Zani, F.; J. Inorg. Biochem. 1995, 57, 43.

17. Banerjee, S.; Mondal, S.; Chakraborty, W.; Sem, S.; Gachhui, R.; Butcher, R. J.; Slawin, A. M. Z.; Mandal, C.; Mitra, S.; Polyhedron 2009, 28, 2785.

18. Johnson, D. K.; Murphy, T. B.; Rose, N. J.; Goodwin, W. H.; Pickart, L.; Inorg. Chim. Acta 1982, 67, 159.

19. Arkis, E. In Tin Chemistry: Fundamentals Frontiers, and Applications; Gielen, M.; Davies, A.; Pannell, K.; Tiekink, E., eds., Wiley: West Sussex, 2008, p. 312.

20. De Lima, G. M. In Tin Chemistry: Fundamentals Frontiers, and Applications; Gielen, M.; Davies, A.; Pannell, K.; Tiekink, E., eds., Wiley: West Sussex, 2008, p. 285.

21. Lacroix, P. G.; Farfán, R. In Tin Chemistry: Fundamentals Frontiers, and Applications; Gielen, M.; Davies, A.; Pannell, K.; Tiekink, E., eds., Wiley: West Sussex, 2008, p. 351.

22. Otera, J.; Biesemans, M.; Pinoie, V.; Poelmans, K.; Willem, R.; Blank, W. J.; Hessell, E. T.; Kinart, W. J.; Kinart, C. M. In Tin Chemistry: Fundamentals Frontiers, and Applications; Gielen, M.; Davies, A.; Pannell, K.; Tiekink, E., eds., Wiley, West Sussex, 2008, p. 667.
23. Pettinari, C.; Marchetti, F. In Tin Chemistry: Fundamentals Frontiers, and Applications; Gielen, M.; Davies, A.; Pannell, K.; Tiekink, E., eds., Wiley, West Sussex, 2008, p. 454.

24. Beraldo, H.; De Lima G. M.; In Tin Chemistry: Fundamentals Frontiers, and Applications; Gielen, M.; Davies, A.; Pannell, K.; Tiekink, E., eds., Wiley, West Sussex, 2008, p. 443.

25. Mendes, I. C.; Costa, F. B.; De Lima, G. M.; Ardisson, J. D.; Garcia-Santos, I.; Castiñeiras, A.; Beraldo, H.; Polyhedron 2009, 28, 1179.

26. Eng, G.; Song, X. In Tin Chemistry: Fundamentals Frontiers, and Applications; Gielen, M.; Davies, A.; Pannell, K.; Tiekink, E., eds., Wiley, West Sussex, 2008, p. 430.

27. Perez-Rebolledo, A.; Ayala, J. D.; De Lima, G. M.; Marchini, N.; Bombieri, G.; Zani, C. L.; Souza-Fagundes, E. M.; Beraldo, H.; Eur J. Med. Chem. 2005, 40, 467.

28. Mendes, I. C.; Moreira, J. P.; Ardisson, J. D.; Gouvêa, Dos Santos R.; Da Silva, P. R. O.; Garcia, I.; Castiñeiras, A.; Beraldo, H.; Eur. J. Med. Chem. 2008, 43, 1454.

29. Recio-Despaigne, A. A.; Da Silva, J. G.; Do Carmo, A. C. M.; Piro, O. E.; Castellano, E. E.; Beraldo, H.; J. Mol. Struct. 2009, 920, 97.

30. Recio-Despaigne, A. A.; Da Silva, J. G.; Do Carmo, A. C. M.; Piro, O. E.; Castellano, E. E.; Beraldo, H.; Inorg. Chim. Acta 2009, 362, 2117.

31. Recio-Despaigne, A. A.; Da Silva, J. G.; Do Carmo, A. C. M.; Sives, F.; Piro, O. E.; Castellano, E. E.; Beraldo, H.; Polyhedron 2009, 28, 3797.

32. Khalil, T.E.; Labib L.; Iskander, M. F.; Polyhedron 1994, 13, 2569

33. Choudhary, S.; Morrows, J. R.; Angew. Chem. Int. Ed. 2002, 41, 4096.

34. CrysAlis RED, Oxford Diffraction Ltd., Version 1.171.32.38. SCALE3 ABSPACK scaling algorithm. CrysAlis RED, Oxford Diffraction Ltd., Version 1.171.32.38.

35. Sheldrick, G. M.; SHELXS-97; Program for Solution of Crystal Structures, University of Göettingen, Göettingen, Germany, 1997.

36. Sheldrick, G. M.; SHELXL-97; Program for Crystal Structures Analysis, University of Göettingen, Germany, 1997.

37. Farrugia, L. J.; J. Appl. Crystallogr. 1999, 32, 837; Farrugia, L. J.; J. Appl. Crystallogr. 1997, 30, 565.

38. National Committee for Clinical Laboratory Standards, Method for Dilution Antimicrobial Susceptibility Tests for Bacteria that Grow Aerobically, NCCLS Document M7-A6, Pennsylvania, USA, 2003, ISBN: 1-56238-486-4.

39. National Committee for Clinical Laboratory Standards, Reference Method for Broth Dilution Antifungal Susceptibility Testing of Yeasts, NCCLS Document M27eMA2 NCCLS, Pennsylvania, USA, 2002, ISBN: 1-56238-469-4.

40. Pérez-Rebolledo, A.; De Lima, G. M.; Speziali, N. L.; Piro, O. E.; Castellano, E. E.; Ardisson, J. D.; Beraldo, H.; J. Organomet. Chem. 2006, 691, 3919. 
41. Ray, A.; Banerjee, S.; Sen, S.; Butcher, R. J.; Rosair, G. M.; Garland, M. T.; Mitra, S.; Struct. Chem. 2008, 19, 209.

42. Yin, H. D.; Chen, S. W.; Inorg. Chim. Acta 2006, 359, 3330.

43. Patole, J.; Sandbhor, U.; Padhye, S.; Deobagkar, D. N.; Anson, C. E.; Powell, A.; Bioorg. Med. Chem. Lett. 2003, 13, 51.

44. Sousa, G. F.; Mangas, M. B. M.; Francisco, R. H. P.; Gambardella, M. T. P.; Rodrigues, A. M. G. D.; Abras, A.; J. Braz. Chem. Soc. 1999, 10, 222.

45. http://www.chemaxon.com/marvin, accessed in March 2010.

46. Jacobson, A. H.; Willingham, G. L.; Sci. Total Environ. 2000, $258,103$.
47. Abbott, A.; Abel, P. D.; Arnold, D.W.; Milne, A.; Sci. Total Environ. 2000, $258,5$.

48. Khan, M. I.; Baloch, M.K.; Ashfaq, M.; Gul, S.; J. Braz. Chem. Soc. 2009, 20, 341.

49. Viñuelas-Zahínos, E.; Maldonado, M. A.; Luna-Giles, F.; Barros-García, F. J.; Polyhedron 2008, 27, 871.

Received: September 14, 2009

Web Release Date: April 12, 2010 